\title{
Geotermikus koncessziós területek értékelésének hazai gyakorlata és a nyilvántartási rendszerekhez való viszonya
}

\author{
Zllahi-Sebess Lászlón ${ }^{1}$, BodA Erika², Gulyás Ágnes ${ }^{1}$ \\ ${ }^{1}$ Magyar Bányászati és Földtani Szolgálat, H-1145 Budapest Columbus utca 17-23. \\ zilahi.sebess.laszlo@mbfsz.gov.hu, gulyas.agnes@mbfsz.gov.hu \\ ²bodaeri@gmail.com
}

\section{The practice of evaluation of recommended areas for geothermal concessions in Hungary and its relation with the register systems}

Abstract

This study briefly describes the recently used Hungarian registration system for geothermal energy and the currently used assessment system for proposed areas for geothermal concessions. With the help of a practical example, a presentation is given of the methodology needed to develop the compliance with an international geothermal evaluation system. For the prioritisation of prospective areas of geothermal research - alongside geological and hydrogeological circumstances - the exploitation feasibility and the socio-economic viability of geothermal energy also need to be considered. Consequently, this becomes more complicated than a simple estimation of reserves based on geoscience. At present, geothermal assets and stock records have no officially accepted international standard; in fact, the "Australian/Canadian standard for research findings, and the reporting of the assets of geothermal stocks" is usually employed in place of an international standard. Even though the development of a Hungarian system similar to the "Australian/Canadian standard" could be aimed at, it would still not be possible to bring about the harmonization between the systems merely by carrying out a direct transfer of existing data. In the Hungarian practice, the terms of calculation and classification of geothermal assets are mixed together. To put it more precisely, it turned out that the current Hungarian classification system is not compatible with any international classification system. A volumetric method is usually used for the prognosis of a geothermal reserve, but the idea of exploitability is not included in the calculation. This study applies the ratio of thermal energy exploitable from hot water and the total heat content of volume in order to calculate exploitable reserves. Geothermal reserves can be established only where a geothermal protective area around the well has been designated and geothermal power generation has started. The inventory calculation data here is based on the data referring to the reserves of an accepted research final report. (This is due to the fact that no identified geothermal protective area is available.) Given that the size of the territory of the protected area is controlled by the desired production quantity, the level of geological knowledge may increase or decrease the calculated value of an area.

Keywords: geothermal energy, registration system, practical example, methodology, Hungary

Összefoglalás

A tanulmányban röviden ismertetjük a hazai geotermikusenergia-nyilvántartási rendszert és a jelenleg a geotermikus koncesszióra javasolt területek értékelési rendszerét. Gyakorlati példán keresztül mutatjuk be, milyen jellegú módszertani háttér kidolgozása szükséges a nemzetközi geotermikus értékelési rendszerekhez való csatlakozáshoz, amelyre vonatkozóan javaslatot tettünk. A geotermikus kutatás szempontjából perspektivikus területek értéksorrendjének megállapításához a földtani, hidrogeológiai viszonyok mellett figyelembe kell venni a geotermikus energia kinyerésének megvalósíthatóságát és a gazdasági-társadalmi életképességet is, mely messze túlmutat a hazánkban elterjedt földtudományokon alapuló készletbecslésen. Geotermikus vagyon- és készletnyilvántartásra jelenleg nincs hivatalosan elfogadott nemzetközi szabvány, de általánosan elfogadott és használt az „Ausztrál/Kanadai Szabvány a kutatási eredmények, geotermikus vagyonok és geotermikus készletek jelentéséhez”. Bár célként megjelölhetô a kanadai-ausztrál szemléletû́ vagyon- és készletnyilvántartáshoz közelítő hazai nyilvántartási rendszer kialakítása, a rendszerek közti harmonizáció nem oldható meg egyszerúen a meglevő nyilvántartási adatok átszámításával. A hazai gyakorlatban összemosódik a geotermikus vagyonszámítás és a geotermikus vagyonosztályozás. Megállapítottuk, hogy a jelenlegi hazai osztályozás nem feleltethetó meg egyik nemzetközi rendszernek sem. A hazai geotermikus prognózisokban általában volumetrikus készletbecslési módszert használnak, ezekben nem jelenik meg a kitermelhetőség fogalma. Tanulmányunkban a koncesszióra javasolt területek geotermikus ásványvagyon értékelésében a vízzel kitermelhető hőmennyiség és teljes hőmennyiség hányadosaként jelenítettük meg a kitermelhető készlet arányát, amivel a hagyományosan kitermelhetősé- 
get jellemezhetjük. Geotermikus készleteket csak ott lehet megállapítani, ahol geotermikus védôidom kijelölésre került, és abból megkezdődött a geotermikus energiatermelés. Jelenleg a készletszámítási adatok az elfogadott kutatási zárójelentés vagyonadatai alapján számszerúsíthetők, mivel geotermikus védőidom nem került még kijelölésre. Ahogy a védőidom területének nagysága a kívánt termelési mennyiségtôl függ, hasonlóképpen a feltártság mértéke befolyással van egy terület értékére.

Tárgyszavak: geotermikus energia, készletnyilvántartás, gyakorlati példa, módszertan, Magyarország

\section{Bevezetés}

Geotermikus vagyon- és készletnyilvántartásra jelenleg nincs hivatalosan elfogadott nemzetközi szabvány, de általánosan elfogadott és használt az „Ausztrál/Kanadai Szabvány a kutatási eredmények, geotermikus vagyonok és geotermikus készletek jelentéséhez" (AGRCC 2010a, b; CGCC 2010). Ettől eltérő alapon múködik a szilárd hasznos ásványi nyersanyagokra és a szénhidrogén-kutatásra kidolgozott projektalapú UNFC-rendszer (Dolle \& FALCONE 2009).

Az elemzésünk során megvizsgáltuk a hazai geotermikus nyilvántartást, illetve a geotermikus energiával kapcsolatos nemzetközi osztályozási rendszereket, majd elemeztük a hazai és nemzetközi geotermikus nyilvántartási rendszerek harmonizációjának lehetőségeit. Meg kell jegyezzük, hogy a nyilvántartási rendszerek általában a kivett víz és energia mennyiségén alapulnak, viszont a területek értéksorrendjéhez szükséges vagyonbecslés kialakításánál a rendelkezésre álló földtani ismeretek részletesebb jellemzését célszerú felhasználni. A területek értéksorrendjének megállapítása túlmutat a készletbecslésen ezért a tanulmányban javasoltunk egy olyan szempontrendszert, amely megjeleníti a kitermelhetôséget és gazdaságosságot befolyásoló tényezôket is.

A nemzetközi ásványvagyon-értékelésről jó áttekintést adott NÁDOR (2016), jelen tanulmány az említett cikkhez kapcsolódik.

\section{A hazai geotermikus nyilvántartási rendszer}

A hazai osztályozás nem konform egyik nemzetközi rendszerrel sem, mert gyakorlatilag csak a termelési adatokon alapul, és nincs szétválasztva a készlet és a vagyon. Ez természetesen a geotermikus energia azon sajátosságából adódik, hogy az mindenütt jelen van, nem csak a térfogat egy részében.

A hazai geotermikus energia nyilvántartási rendszer a Bányatörvény 2014. évi módosításnak megfelelően új szerkezetben került kialakításra, amely négy, logikailag egymásra épülő táblázatból áll (NÁDOR 2016). A hőmennyiségnyilvántartás a geotermikus energiát hasznosítók önbevallása alapján történik.

1. A vagyonnyilvántartás az alábbi elemeket tartalmazza:
A) Név,
B) Koordináták,
C) Terület nagysága,

D) Tárgyévet megelőző évi vagyon (GJ),

E) Kutatás (Vagyonváltozás tárgyévi kutatás miatt),

F) Átszámítás (Vagyonváltozás tárgyévi átszámítás miatt),

G) Korrekció (Vagyonváltozás adatszolgáltatási korrekció miatt),

H) Utánpótlódás (GJ) (terület × hőáram),

I) Kitermelt energia (Tárgyévben kitermelt energia),

J) Vagyon $(G J)=C+D+E+F+G+H$.

A geotermikus vagyonnyilvántartás elemeiből a koordinátákkal a terület nagysága és a kitermelt energia értéke mérhetô, a többi elem becsült vagy származtatott értéknek tekinthetô. Ennek okán a vagyon nagyságára vonatkozó paraméterek bizonytalannak tekintendók. Amennyiben a térfogat által képviselt teljes, egyben a felszíni hômérséklethez számított hőtartalmat tekintjük, az csak reménybeli vagyonnak számít, mert valójában nem lehet kitermelni. Ennek oka elsősorban a kőzetek rossz hővezető-képessége.

2. A védóidom-nyilvántartás az alábbi elemeket tartalmazza:

„A geotermikus védőidom-nyilvántartás tartalmazza a védőidom alakjának egyértelmú meghatározásához szükséges mennyiségú térbeli pontok $\mathrm{x}$, y és z koordinátáit, a kijelöléshez felhasznált múszaki és földtani alapadatokat, valamint módszereket és számításokat." (Bányajog)

3. A geotermikus védóidom nyilvántartás:

A létesítmény-nyilvántartás csak az azonosításhoz szükséges adatokat tartalmazza (koordináták, tulajdonosra és engedélyre vonatkozó adatok).

4. A termelésre vonatkozó nyilvántartás a következő paramétereket tartalmazza:

- MBFH kútazonosító;

— kút jele.

A geotermikus energiatartalom becslése nem azonos a potenciál becslésével, éppen ezért idézzük a geotermikus potenciál és a geotermikus energia definícióját:

A geotermikus potenciál - az International Geothermal Association (IGA) ajánlása alapján - az egy év alatt megtermelhetô geotermikus energiamennyiség.

Az ide vonatkozó meghatározó hazai jogszabály, a Bányatörvény (Bt. 1993. évi XLVIII. törvény 49. § 11.) alapján a geotermikus energia a földkéreg belsố hôenergiája. Ez azonban nem tekinthetô potenciálnak, helyette inkább csak egy a felszínhez viszonyított relatív értéket ad, egyfajta reménybeli vagyont, amelyben nincs utalás a kitermelhetôségre.

Számos más nyersanyaggal ellentétben hazánkban a geotermikus energia vagyon-/készletkategóriákba sorolása nem valósult meg. A termelésre vonatkozó nyilvántartás és a vagyonnyilvántartás nem helyettesíti a készletkategóriákba sorolást. A készletkategóriákba sorolást viszont megálla- 
pított geotermikus védőidomok nélkül nem lehet megtenni. Ettôl függetlenül a geotermikus energia nagysága becsülhetô, ha egy nagyobb területre és mélységközre végezzük a becslést, és öröklött hőként kezeljük. Számos becslés készült a geotermikus energia magyarországi mennyiségére vonatkozóan (I. táblázat). A becsült mennyiségek közül a teljes belső energiatartalom egy a felszíni átlaghőmérséklethez képest számított mennyiség, amely a reménybeli vagyon kategóriát jelenti, viszont kiszámítása kevés szubjektív elemet tartalmaz'. Ezért ez az egyetlen biztos, kis hibahatárral meghatározható szám. (A kéreg felső $5000 \mathrm{~m}$ vastagságú részére minden szakértő néhány százalék eltéréssel $10^{23}$ Joule, azaz százezer EJ energiatartalmat ad meg. mely részben magyarázható a számításba vont eltérô mélységtartományokkal. De a fố ok az, hogy nem mindig teljes térfogatról, hanem annak egy részéről van szó, ahonnan mozgatható vízzel ki lehet termelni hőenergiát.

További körülmény, hogy a geotermikus potenciál az IGA definíció alapján is egy szabvány paraméterekkel rendelkező eszközt feltételez, ami akár az egész belső energia is lehet. Ha az egységeszköz (ami részben technikai, részben közgazdaságtani fogalom) definiálásától eltekintünk, akkor a továbbiakban a reménybeli vagyon különböző szempontok szerinti felosztásáról beszélhetünk. Ez elsôsorban hidrogeológiai és hőtani paraméterek becslését jelenti, amelynek alapján becsüljük egy adott térfogat hőenergia-tartalmát

I. táblázat. Magyarország geotermikus készletbecsléseinek összehasonlitása (ZILAHI-SEBESS et al. 2012)

Table I. Comparison of the geothermal evaluation systems in Hungary (ZILAHI-SEBESS et al. 2012)

\begin{tabular}{|c|c|}
\hline Földtani vagyon $=$ Kezdeti földtani készlet & $\begin{array}{c}\text { Hozzáférhetó } \\
\text { geotermikus } \\
\text { készlet nagysága }\end{array}$ \\
\hline 0-10 km-es mélységtartományban lineárisan extrapolált hömérsékletváltozás feltételezésével (BoLDIzsár 1967) & $5,53 \times 10^{8} \mathrm{PJ}^{\mathrm{a}}$ \\
\hline 0-10 km-es mélységtartományban nem-lineáris hőmérsékletváltozás feltételezésével (ВовоК 1987, ВовоК, То́тн 2010) & $3,25 \times 10^{8} \mathrm{PJ}$ \\
\hline 0-10 km-es mélységtartományban nem-lineáris hőmérsékletváltozás feltételezésével (ZILAHI-SEBESS et al. 2012) & $3,75 \times 10^{8} \mathrm{PJ}$ \\
\hline \multicolumn{2}{|l|}{ Reménybeli geotermikus vagyon (prognosztikus vagyon) } \\
\hline 0-4 km-es mélységtartomány (Вовок 1987, Вовок, То́тн 2010a ) & $0,855 \times 10^{8} \mathrm{PJ}^{\mathrm{b}}$ \\
\hline 0-5 km-es mélységtartományban a kôzetvázban és a vízben tárolt teljes hőmennyiség (RezEssy et al. 2005) & $1,02 \times 10^{8} \mathrm{PJ}$ \\
\hline 0-5 km-es mélységtartományban a kőzetvázban és a vízben tárolt teljes hömennyiség (ZILAHI-SEBESS et al. 2012) & $1,055 \times 10^{8} \mathrm{PJ}$ \\
\hline $\begin{array}{l}\text { 0-2400 méter mélységközben tárolt termálvízből kitermelhetôn geotermikus energiavagyon (fluidum) (LIEBE et al. 1982, } \\
\text { LORBERER 2004) }\end{array}$ & $5,73 \times 10^{5} \mathrm{PJ}$ \\
\hline $\begin{array}{l}\text { 0-2400 méter mélységközben tárolt termálvízböl és a porózus tárolóból kitermelhetö geotermikus energiavagyon (közetváz } \\
\text { + fluidum) (LIEBE et al. 1982, LORBERER 2004) }\end{array}$ & $1,49 \times 10^{6} \mathrm{PJ}$ \\
\hline $\begin{array}{l}\text { 0-2400 méter mélységközben tárolt termálvízbőll és a porózus tárolóból (közetváz + fluidum) } 25^{\circ} \mathrm{C} \text { hốmérsékletü } \\
\text { vízvisszatáplálást feltételezve kitermelhetô geotermikus energiavagyon (LIEBE 1982, LORBERER 2004) }\end{array}$ & $3,43 \times 10^{5} \mathrm{PJ}$ \\
\hline Felsö-pannóniai összletben tárolt hőmennyiség (közetváz + fluidum) (REzessy et al. 2005) & $4,66 \times 10^{6} \mathrm{PJ}$ \\
\hline Hőszivattyúzással + pannóniai összletböl + karbonátos aljzatból hévízzel kitermelhetö (ВовОК 1987, Вовок, То́тн 2010a) & $4,54 \times 10^{5} \mathrm{PJ}$ \\
\hline $\begin{array}{l}\text { A teljes felsö-pannóniai üledéksorra becsült érték, az effektiv porozitásban tárolt teljes kitermelhetô vízkészlettel elvileg } \\
\text { kivehetö hömennyiség (fluidum) - a kitermelési technológia figyelembevétele nélkül (ZILAHI-SEBESS et al. 2012) }\end{array}$ & $1,637 \times 10^{6} \mathrm{PJ}$ \\
\hline $\begin{array}{l}\text { A teljes negyedidöszak+pannóniai üledéksorra becsült érték, az effektív porozitásban tárolt teljes kitermelhetō vízkészlet } \\
\text { (fluidum) búvárszivattyúval ténylegesen kitermelhetö (kb. 10\%-ában tárolt) hömennyiség (ZiLAHI-SEBESS et al. 2012) }\end{array}$ & $3,07 \times 10^{5} \mathrm{PJ}$ \\
\hline
\end{tabular}

${ }^{a}$ BoLDIZSÁR becslése csak a lineárisan extrapolált hőmérséklet miatt nagyobb a másik kettőnél.

${ }^{\mathrm{b}}$ Ha feltételezzük, hogy 5000 m-ig a felszínhez képest számított átlaghőmérséklet 20-25\%-t emelkedik akkor 1,026-1,068×108 PJ tartományba esik az 5000 m-ig számított becslés, azaz majdnem ugyanaz, mint a REZESSY (2005), illetve a ZiLAHI-SEBESs et al (2012) -féle becslés.

A többi nyersanyag esetében a reménybeli kategória számít a leginkább bizonytalannak, mivel a teljes keletkezett nyersanyag mennyisége nagyon nehezen becsülhető még nagyságrendileg is.)

A hozzáférhető geotermikus készlet ${ }^{2}$ nagyságát illetôen a becslések némely esetben több nagyságrenddel szórnak,

\footnotetext{
${ }^{1} \mathrm{Az}$ energiatartalmat, amennyiben termál energiáról van szó, szokás a $30{ }^{\circ} \mathrm{C}$ feletti hőmérsékletủ energiaként definiálni.

${ }^{2}$ A hozzáférhető geotermikus készlet az 5 kilométer mélységig kitermelhető hőmennyiségre vonatkozik. Ez nagyjából a mélyfúrásokkal elérhető tartomány. Noha léteznek ennél mélyebb fúrások is, azonban egy készletszámításnál, különösen Magyarországon, nem jelentenek reális lehetőséget a kitermelésre.
}

amely lehet például az effektív porozitás hőenergia-tartalma $30^{\circ} \mathrm{C}$ feletti része.

Földtudományi szempontból a potenciál helyett a készletbecslés és egy jól definiált egységeszközzel való kitermelhetôség fogalma túnik eredményes megoldásnak. Meg kell említeni, ha nem definiáljuk, hogy milyen eszközzel akarunk termelni, nem értelmezhetô maga a potenciál, sôt a készlet fogalma sem.

Az I. táblázat értékeinek kategóriánkénti jelentôs eltérése több esetben a mélységi értelmezési tartomány különbözőségére vezethetô vissza, illetve szemléletbeli különb- 
ségeket tükröz (és nem a számolási módszerek különbözőségére vezethetố vissza). Lényeges, hogy a táblázat adatai nem tekinthetôk valójában potenciálnak, hanem vagyoni kategóriáknak.

A hazai geotermikus prognózisok mindegyikében volumetrikus készletbecslési módszert használtak a szerzók, ezért azokban valójában nem jelenik meg a kitermelhetôség fogalma. Lényegében mindegyik becslés helyben tárolt hő́t jelent. A volumetrikus becslés a teljes térfogat egyes elemeinek, (porozitás, kôzetmátrix) mélységintervallum vagy földtani egységenkénti statikus hőtartalmát jelenti.

\section{Geotermikus területek értéksorrendjének megállapítása}

A területek geotermikus potenciál szerinti rangsorolását megelőzően az összehasonlíthatóság érdekében célszerú egy etalonterületet kiválasztani, melynek segítségével elvégezhetố a további területek alábbi értékelése. A terület értékelés szempontjai messze túlmutatnak a földtudományokon alapuló készletbecslésen.

Elsô közelítésben az alábbi három szempont szerint lehet jellemezni egy területet:

— Földtani megkutatottság.

— Természetvédelmi területekkel való lefedettség.

- CH-termeléssel való interferencia.

Ez a szempontrendszer elég egyszerú összehasonlítást enged meg a területek között, így nem ad megfelelő támpontot a területek relatív értéksorrendbe állításához. Ezért több terület minősítése esetén javasoljuk az alábbi tényezók figyelembevételét is:

1. Terület nagysága,

2. Ismeretesség (fúrás, szeizmikus szelvény száma stb.),

3. Vagyon nagysága,

4. Kitermelhetôség (a hidrogeológiai tulajdonságok mellett technológiafüggó is),

5. Korlátozások területi kiterjedése (pl. természetvédelmi területek, utak, városok stb.),

6. A korlátozások általános jellege,

7. Hőpiac nagysága,

8. Más nyersanyagokkal (pl. olaj, gáz, víz, egyéb) való interferencia,

9. A szabadon maradó terület nagysága.

A geotermikus energia vagyonba vagy készletbe sorolását csak védőidommal lehatárolt konkrét területek esetén lehet meghatározni. Ezért a koncessziós területek kijelölése után megkezdődött a területek minősítése, egységes szempontrendszer szerinti pontozása és rangsorolása. Ez azonban még nem egyenértékú a területek nemzetközi osztályozási rendszerekbe sorolásával, csak területek egymáshoz viszonyított értékének megállapítása volt a cél.

A geotermikus koncessziós területek értéksorrendjének megállapításához a (készlet nagyságát meghatározó) földtani ismeretek mellett figyelembe kell venni a geotermikus energia kinyerésének megvalósíthatóságát és a gazdaságitársadalmi életképességet is. A földtani-gazdasági-meg- valósíthatósági tényező́k alkotta keretrendszer alapján a II. táblázatban felsorolt információk együttes felhasználásával soroltuk csoportba a geotermikus energia kinyerésére alkalmas területeket. Az egyes tényezók számításait az 1. számú elektronikus melléklet tartalmazza.

II. táblázat. A geotermikus energia kinyerésére alkalmas területek csoportba sorolásának szempontjai

Table II. Criteria of the classification of the areas available for geothermal energy extraction
a) Terület
b) Ismertség (megkutatottság)
c) Hagyományos vagyon
d) Vagyon (mátrix+porozitás)
e) Kitermelhetőség (áramló vízzel kitermelhetô hányad)
f) Korlátozások területe
g) Szigorú korlátozások jellege ${ }^{a}$
h) Ipari faktor
i) Lakosság
j) Hőpiac nagysága faktor
k) Interferencia (CH-termeléssel)
1) Szabadon maradó terület hányada
m) Teljesen zavartalan terület hányada
n) Hozzáférhetőségi index ${ }^{\mathrm{b}}$
o) Területre normált hozzáférhetőségi index
p) Megbízhatóan hozzáférhetősége
q) Megtalálhatósági faktor ${ }^{c}$
Származtatott értékek
r) Területarányos értékszorzat
s) Területarányos értékfaktor
t) Fajlagos értékszorzat
u) Fajlagos értékfaktor
v) Fajlagos értékfaktor szerinti sorrend.

a A szigorú korlátozások területén (pl. Natura 2000) nem végezhető felszíni bányászati tevékenység, míg a többi nem jelent teljes tilalmat

${ }^{\mathrm{b}}$ Hozzáférhetőségi index $=($ Hagyományos vagyon $\times$ Kitermelhetőség $)$, ahol a kitermelhetőség a vízzel kitermelhető mennyiség és a teljes hőmennyiség aránya a kitermelhetőség, azaz egyszerüsítve a hagyományos vagyon a négyzeten osztva a teljes hőmennyiséggel. A hozzáférhetőség névben az van benne, hogy nem egyszerủen a teljes hőmennyiséghez viszonyítjuk a vízzel kitermelhetöt, hanem formálisan figyelembe vesszük azt is, hogy minél kisebb a hézagtérfogat-arány, annál kisebb a szivárgási tényező, azaz annál nehezebben férünk hozzá a hőtartalomhoz. Ez valódi eseteket vizsgálva nem feltétlenül igaz, hiszen kis hézagtérfogathoz is tartozhat nagy áteresztőképesség.

${ }^{\mathrm{c}}$ A megtalálhatósági faktor (területarányos megbízhatóan hozzáférhetőség) $=$ terület $(\mathrm{b}) \times$ Ismeretesség $(\mathrm{c}) \times$ Hagyományos vagyon $(\mathrm{d}) \times$ Kitermelhetőség $(\mathrm{f}) /$ terület $(\mathrm{b})=\mathrm{c} \times \mathrm{d} \times \mathrm{f}$. Azaz a megtalálás esélye arányos a területtel.

Az a)-tól o)-ig felsorolt szempontokból származnak az r)-tôl v)-ig felsorolt mutatók.

A fenti szempontok szerinti értékelésre a III. táblázat mutat be egy példát.

A területi értékelés során meghatározásra került ismertségi (megkutatottsági) értékek segítségével (IV. táblázat) az egyes koncessziós területek megfeleltethetôek az ausztrálkanadai rendszer kategóriáinak.

Ehhez figyelembe kell venni, hogy az egyes geofizikai mérésfajtáknak különböző az információs értéke. Például nem mindegy, hogy rendelkezésre áll-e 3D szeizmika a területen, vagy olyan nagymélységú fúrás, amiben történt digitális mélyfúrás-geofizikai szelvényezés. Ezért az összesített statisztikában minden megjelölt mérésfajtához egyegy súlyfaktort rendeltünk, ami kifejezi a terület feltárá- 
III. táblázat. Javasolt területértékelési táblázat

Table III. Table of recommended criteria for estimation of relative value of the areas

\begin{tabular}{|c|c|c|c|c|c|c|}
\hline a) Koncesszióra javasolt terület neve & $\mathrm{Me}$ & Etalonterület & $\begin{array}{c}\text { A } \\
\text { terïlet }\end{array}$ & $\begin{array}{c}\mathrm{B} \\
\text { terïlet }\end{array}$ & $\underset{\text { terület }}{\mathrm{C}}$ & $\begin{array}{c}\mathrm{D} \\
\text { terïlet }\end{array}$ \\
\hline b) Terület nagysága & $\mathrm{km}^{2}$ & 250 & 525 & 419 & 400 & 394.58 \\
\hline c) Ismeretesség (Megkutatottság) & & 1 & 0.5 & 2 & 2,5 & 2,5 \\
\hline d) Hagyományos vagyon & PJ & 156 & 108 & 233 & 27 & 112 \\
\hline e) Vagyon (Mátrix+porozitás) & PJ & 18423 & 1865 & 9160 & 780 & 20280 \\
\hline $\begin{array}{l}\text { f) Áramló vízzel kitermelhetö hányad }(2,5-5 \text { km } \\
\text { közt) }\end{array}$ & & 0,01 & 0,06 & 0,03 & 0,03 & 0,01 \\
\hline g) Korlátozások területe & $\mathrm{km}^{2}$ & 254 & 131 & 84 & 111 & 117 \\
\hline h) Szigorú korlátozások jellege & & Natura2000 & & & & \\
\hline i) lpar faktor & & 5 & 100 & 5 & 5 & 25 \\
\hline j) Lakosság & fó & 20000 & 113000 & 3700 & 30000 & 27000 \\
\hline k) Höpiac nagysága faktor & & 1 & 20 & 1 & 1 & 5 \\
\hline 1) Interferencia (CH-termeléssel) & & 1 & 0,5 & 0,5 & 2 & 2 \\
\hline m) Szabadon maradó területhányad & & 0,3 & 1,0 & 0,9 & 0,7 & 0,9 \\
\hline n) Teljesen zavartalan területhányad & & 0,2 & 0,8 & 0,8 & 0,7 & 0,7 \\
\hline o) Hozzáférhetöségi index & & 1,3 & 6,3 & 5,9 & 0,9 & 0,6 \\
\hline p) Területre normált hozzáférhetőségi index & & 0,004 & 0,012 & 0,014 & 0,003 & 0,002 \\
\hline q) Megbízhatóan hozzáférhetöség & & 0,004 & 0,006 & 0,028 & 0,006 & 0,004 \\
\hline r) Megtalálhatósági faktor & & 1,3 & 3,1 & 11,8 & 2,3 & 1,5 \\
\hline s) Területarányos értékszorzat & & 25 & 46808 & 6751 & 204 & 947 \\
\hline t) Területarányos értékfaktor & & 1,4 & 4,7 & 3,8 & 2,3 & 3,0 \\
\hline u) Fajlagos értékszorzat & & 0,1 & 89,1 & 16,1 & 0,6 & 2,4 \\
\hline v) Fajlagos értékfaktor & & 0,9 & 3,9 & 3,2 & 1,8 & 2,4 \\
\hline w) Fajlagos értékfaktor szerinti sorrend & & 15 & 1 & 8 & 11 & 10 \\
\hline x) Területarányos értékfaktor szerinti sorrend & & 15 & 1 & 7 & 11 & 10 \\
\hline
\end{tabular}

Me = mértékegység.

IV. táblázat. Geofizikai megkutatottsági indexek ${ }^{3}$

Table IV. Geophysical research indexes

\begin{tabular}{|l|c|c|c|c|}
\hline \multicolumn{1}{|c|}{ Mérés megnevezése } & Súlyfaktor & Darab & Érték & $\begin{array}{c}\text { Területre normált érték } \\
\left.\text { (a terület nagysága } 525 \mathrm{~km}^{2}\right)\end{array}$ \\
\hline 2500 m-nél mélyebb fúrás & 250 & 1 & 250 & 0,48 \\
\hline Digitális karotázs & 250 & 1 & 250 & 0,48 \\
\hline Geotermikus adat & 100 & 43 & 4300 & 8,19 \\
\hline VSP, szeizmokarotázs & 100 & $2+5$ & 700 & 1,33 \\
\hline 2D szeizmika & 250 & 57 & 14250 & 27,13 \\
\hline 3D szeizmika & 1000 & 0 & 0 & 0 \\
\hline Gravitációs & 1 & 2648 & 2648 & 5,04 \\
\hline Mágneses $\Delta Z, \Delta \mathrm{T}$ & 1 & 271 & 271 & 0,51 \\
\hline Mágneses légi $\Delta \mathrm{T}$ & 25 & 0 & 0 & 0,00 \\
\hline Tellurika (TE) & 10 & 20 & 200 & 0,38 \\
\hline Magnetotellurika (MT) & 50 & 21 & 1050 & 2 \\
\hline VESZ (nagy mélységü)) & 10 & 31 & 310 & 0,59 \\
\hline Összeg & & & 24229 & 46,12 \\
\hline
\end{tabular}

Referenciaterültre normált érték: 0,5

${ }^{3}$ Egy általánosabb kibővített földtani megkutatottsági index további vizsgálatokat is tartalmazhatna. Ezek közül a hidrodinamikai kútteszteket tartjuk a legfontosabbnak, mint a kitermelhetőség megitélését leginkább befolyásoló tényezőt. A hidrodinamikai vizsgálatok megléte, javaslatunk szerint, másfélszer növelheti az ismeretességi indexet a fúrással feltárthoz képest. A megfelelő mélységủ fúrás jelenléte is önmagában kétszeres szorzót jelent a javaslatban. A fluidumbányászatban a közvetlen magvizsgálatoknak nincs túl nagy jelentősége, miután azok pontszerủek, és nem is az eredeti állapotot képviselik, ezért általában nem reprezentatívak. Nagy jelentőséget tulajdonítunk még a vízkémiai vizsgálatoknak. 
sában betöltött mértékét. Természetesen lehet ennél jóval árnyaltabban különbséget tenni az egyes mérésfajták közt, azonban ahhoz jóval részletesebb statisztikára volna szükség, ahol a különböző fúrólyukinformációk között is különbséget teszünk. Példának okáért az akusztikus, illetve a sưrúség és a neutronporozitás mérése jóval nagyobb értékúvé teszi fúrást, mert ezek valamennyien porozitáskövetók, és mint ilyenek a kvantitatív értelmezés alapját képezik.

Ennek megfelelően a megkutatottsági index táblázatában az egyes mérésfajtáknak súlyfaktort adtunk, amely az egyes méréseknek, mint a statisztikai egységeknek az információs súlyát fejezi ki. Az 5. oszlopban az összeg a folyamatos megkutatottsági index. Az 5. oszlop alapján az etalonterület területre normált értékét (390) egységnyinek tekintve egy 0,5 egység ugrásokkal kategorizált ismertségi számot adtunk a területnek. Ezen eljárás során nem vesszük figyelembe külön súllyal, hogy egy összletrôl van-e fúrásos információ, vagy azon belül hidrodinamikai információ. A 3D szeizmika és kellő számú digitális karotázsmérés látszólag pótolja a megfelelő mélységú, a céltérfogatot harántolt fúrást, ami hátrányosan érintheti egy adott terület értékelésének hitelességét.

Véleményünk szerint valójában semmi nem kompenzálhatja a vizsgálandó objektumot harántoló fúrás hiányát. Ezért szükséges az értékelési szempontokat tovább finomítani. A fentieket figyelembevevő módosított megkutatottsági indexben bizonyos paraméterek meglétéhez kötjük a magasabb ismertségi osztályba sorolást hasonlóan az ausztrál-kanadai rendszer ismeretességi kategóriájához. Az ismertség jobb differenciálása érdekében különbséget kell tenni azon területek közt, ahol van 3D szeizmika és ahol nincs. Javasoljuk, hogy ahol van megfelelő mélységú fúrás és 3D szeizmika is, ott a szorzó legyen 2, azaz ha az eredeti megkutatottsági index 0,5 lenne, akkor az 1-re javul. Ahol nincs 3D szeizmika, ott az ismertség mérôszámát 0,75-tel szorozzuk. Azaz 3D szeizmika és fúrás hiányában a szorzó 0,75 . Ha van már fúrás a területen, de 3D szeizmika nincs, akkor ez a szorzó 1,5 lenne, míg ha 3D szeizmika van, de megfelelő fúrás nincs, akkor csak 1. Azaz a fúrás meglétének elónyeit nem ronthatja le még a 3D mérés hiánya sem.

$\mathrm{Az}$ ezt is figyelembevevő módosított megkutatottsági indexben a megkutatottságot több osztályba soroljuk, amely az alábbiak szerint illeszkedik az ausztrál-kanadai rendszer kategóriáihoz:

- Fúrással nem feltárt vagyon ${ }^{4}$ értékszorzó 1, mely a következtetett geotermikus vagyonnak felel meg

- Fúrással, de hidrodinamikai vizsgálatok nélkül feltárt vagyon ${ }^{5}$ : értékszorzó 2 , amely a felderített geotermikus vagyonnak felel meg.

- Fúrással és hidrodinamikai méréssel is feltárt va-

${ }^{4}$ A következtetett (Inferred Geothermal Resource): Alacsony megbízhatósági szinten becsülhető geotermikus vagyon. A következtetett geotermikus vagyon esetén a tároló kiterjedése és kapacitása feltételezett, fúrással nem feltárt, azonban egyéb mérési adatokon alapuló földtani megfontolásokból, analógiákból következtetni lehet rá.

${ }^{5}$ Felderitett geotermikus vagyon (Indicated Geothermal Resource): Elöre definiált megkutatottsági indextartomány alapján közepes megbizhatósági szinten becsülhető geotermikus vagyon. A felderített geotermikus vagyon a tároló hőmérsékletére és gyon $^{6}$ : értékszorzó 3, amely a megkutatott geotermikus vagyonnak felel meg.

Az ausztrál-kanadai rendszer, az eddig alkalmazott Magyar Ásványvagyon rendszer és az MFGI által 2013-ban javasolt rendszerek megfeleltethetőségét tartalmazza a 2 . elektronikus melléklet.

\section{Gyakorlati példa}

A már értékelt területeken az új szempontok szerinti értékelés az UNFC szempontok érvényesítése érdekében elsősorban az ismertséget használó kategorizáláson alapuló ausztrál-kanadai kóddal kapcsolja össze a területek értéksorrendjét. Az értékelés a már az interneten is nyilvánosan hozzáférhetó koncessziós vizsgálati jelentésekre alapoz. A 17 terület közül a javított megkutatottsági index szerint négynek nem változott a sorrendszáma, míg a területnagyságra normált érték vizsgálatával nyolc esetben változik a sorrendszám. A változás a legtöbb esetben csak egy-egy hely, kivéve azon terület esetében, amely a 2500 m-nél mélyebb fúrás hiányában jelentôsen hátrébb sorolódott az ismertségi rangsorban. Az V. táblázat az eddigi 17 konceszszióra javasolt területből négynek az aktualizált értékelését tartalmazza. A fajlagos értékfaktor szerinti sorrendben a sorszám és a területarányos értékfaktor szerinti sorszám a táblázat jobb szélén található az egyes területeknél. Az értékek azt fejezik ki, hogy az 5 km mélységig tárolt hőmennyiségnek hányad része a vízzel kitermelhetô, illetve hányad része a repedésekkel átjárt rész (hozzáférhetô) hôtartalma. A hagyományos vízzel, visszasajtolás nélkül kitermelhető hőmennyiség és a hozzáférhető hőmennyiség egyaránt a repedésekkel átjárt térfogatrészből származik.

Az UNFC értékelés G-tengelyének kategóriáihoz elsősorban a vagyon nagysága szerinti kategóriák megadásakor tekintetbe kell venni azonban, hogy megfelelő mélységú fúrás nélkül bármely értékelés nagymértékben becsléseken alapul.

Az említettek miatt ezeken a javasolt területeken érdemesnek tartjuk annak további vizsgálatát, hogy miként ültethetó át a gyakorlatba az UNFC három tengelyen megjelenített szempontrendszere.

Vállalkozókkal való konzultáció során felvetődött, hogy a földtani ismertség nem feltétlenül egy terület értékét növelő elóny. A földtani ismertség (megkutatottság) értéke valójában a kívánt termelési szinttől függ. Nagy elvárt termelés esetén a túl jó ismertség azt jelentheti, hogy már nincs mit keresni, az adott mérettartományban már minden rezervoárt megtaláltak. Ellenben kisebb mértékú elvárt

kiterjedésére irányuló direkt mérések alapján igazolható. A felderített geotermikus vagyon kitermelhető része és a kihozatali tényező értéke kielégitő biztonsággal becsülhető.. A lényeg, hogy legalább egy a feltételezett tárolót harántoló fúrás van.

${ }^{6}$ Megkutatott geotermikus vagyon (Measured Geothermal Resource): Magas megbízhatósági szinten becsülhető geotermikus vagyon. A megkutatott geotermikus vagyon a tároló hőmérsékletére, kiterjedésére vonatkozó direkt mérések, illetve a lefúrt kútban elvégzett helyszini (kútvizsgálat és karotázs) mérések alapján magas megbízhatósági szinten meghatározható. A kapacitásvizsgálatok, illetve egyéb tesztek alapján a megkutatott geotermikus vagyon kitermelhető része és a kihozatali tényező értéke is megbízhatóan becsülhető 


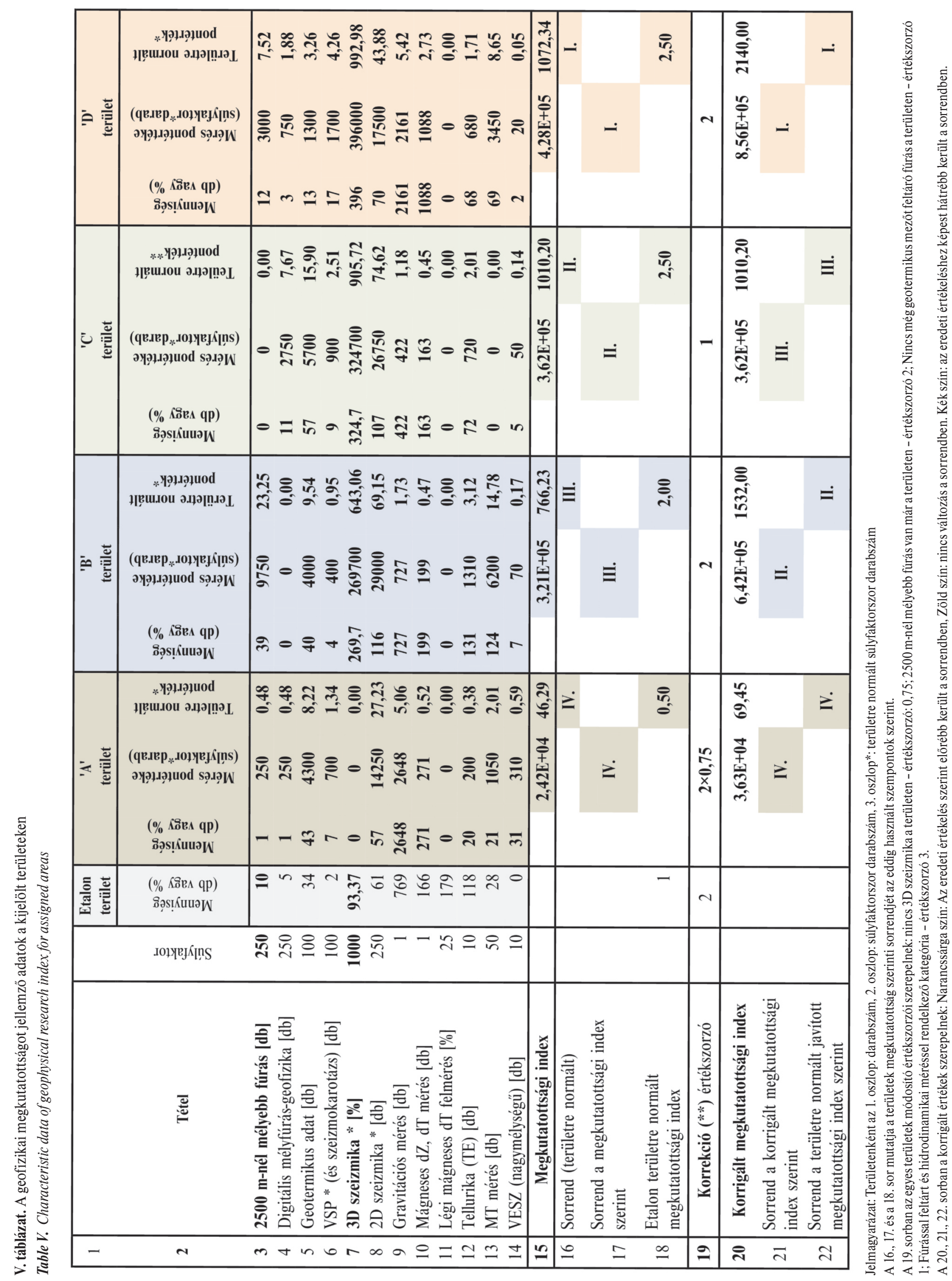




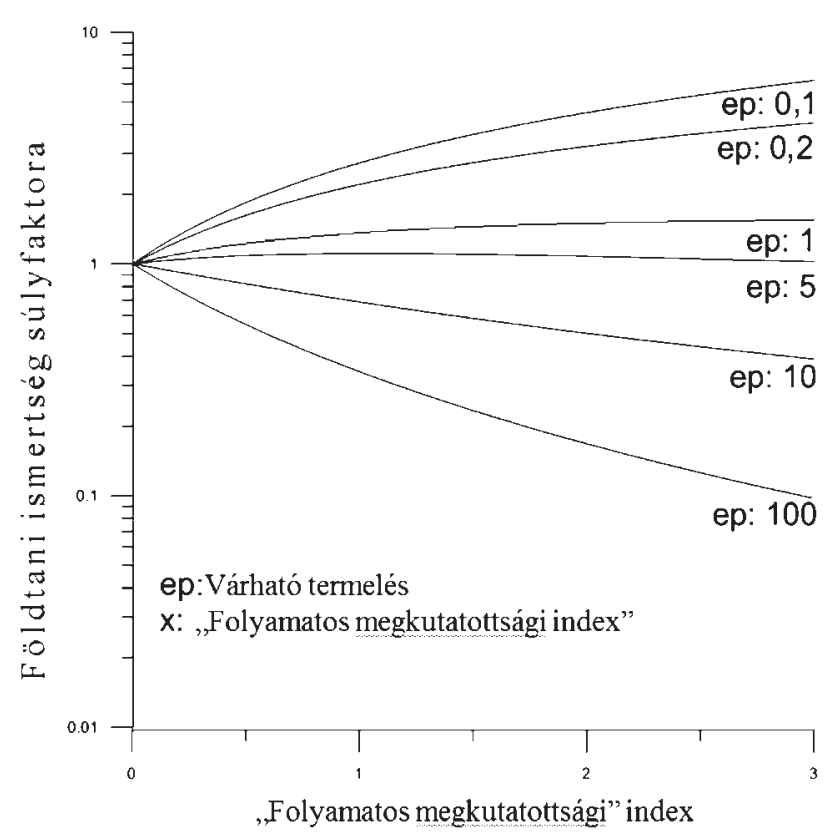

1. ábra. A javasolt földtani ismertségi súlyfaktor függése a megkutatottsági indextől. A folyamatos megkutatottsági index a IV. táblázat összeg sorának a logaritmusa

Figure 1. The recommended weight factor of geological knowledge as a function of research index with the parameter of demanded productivity (The continuous research index is the logarithm of the bottom row of Table IV

termelést könnyebb teljesíteni, mivel valószínúbben valósul meg. Ezt próbafüggvényben is megjelenítettük (1. ábra, ZILAHI-SEBESS \& BoDA 2015). A folyamatos megkutatottsági index a II. táblázat összeg sorának a logaritmusa. A javasolt földtani ismertségi súlyfaktor viszont egy olyan szám, amit a területértékelés alapján valóban célszerú használni, mivel az nem tartható álláspont, hogy az értékelés során egyszerúen hagyjuk el a megkutatottságot. Az egyes görbék paramétere a várható termelési érték, ami az ábrán csak egy fiktív és relatív szám, azaz nem jelent valóságos, az ábra alapján közvetlenül fizikai egységben (a geotermikában pl. PJ-ben) kifejezhetô értéket.

Más szavakkal, mivel a terület értékét akarjuk kifejezni, simán egy megkutatottsági mérőszám nem fejezi ki azt, hiszen nagy várható termelési igénynél a lehetséges új találat esélyét rontja a túlzott ismertség, ám ha csak kis termelési szintet tervezünk, akkor az ismertség előnyös. Az természetesen nyitott kérdés marad, hogy egy adott technológiánál melyik az a termelési szint, ahol hátrányos a több ismeret.

\section{Összegzés}

A geotermikus kutatás szempontjából perspektivikus területek értéksorrendjének megállapításához a földtanivízföldtani viszonyok mellett figyelembe kell venni a geotermikus energia kinyerésének megvalósíthatóságát és a gazdasági-társadalmi életképességét is. Ez messze túlmutat a hazánkban elterjedt földtudományokon alapuló készletbecslésen.

A területi értékelés során meghatározott módosított ismertségi értékek segítségével a minősített területek megfeleltethetôek az ausztrál-kanadai rendszer kategóriarendszerének:

- Fúrással nem feltárt értékszorzó 1, mely a következtetett geotermikus vagyonnak felel meg

— Fúrással hidrodinamikai vizsgálat nélkül; értékszorzó 2, amely a felderített geotermikus vagyonnak felel meg.

- Fúrással feltárt és hidrodinamikai méréssel rendelkezô kategória; értékszorzó 3, amely a megkutatott geotermikus vagyonnak felel meg.

A kanadai-ausztrál szemléletú vagyon- / készletnyilvántartáshoz közelítő hazai nyilvántartási rendszer kialakítása, azaz a harmonizáció nem oldható meg egyszerúen a meglevő nyilvántartási adatok átszámításával. A hazai geotermikus prognózisok mindegyikében volumetrikus készletbecslési módszert használtak a szerzôk, ezért azokban valójában nem jelenik meg a kitermelhetôség fogalma.

Geotermikus készleteket csak ott lehet megállapítani, ahol geotermikus védőidom kijelölésre került, és abból megkezdődött a geotermikus energiatermelés. A készletszámítási adatok itt alapvetően az elfogadott kutatási zárójelentés vagyonadatai alapján végezhetőek el.

Nincs egységesen elfogadott nemzetközi osztályozási rendszer. A hazai gyakorlatban összemosódik a geotermikus vagyonszámítás és a geotermikus vagyonosztályozás. Végezetül pedig megállapítható, hogy a jelenlegi hazai osztályozás nem felel meg egyik nemzetközi rendszernek sem.

\section{Köszönetnyilvánítás}

A szerzők megköszönik az MBFSZ vezetőjének, Dr. FANCSIK Tamás elnök úrnak, hogy támogatta a tanulmány megjelenését, valamint megköszönjük a lektorok különösen ÁDÁM László előremutató megjegyzéseit ezzel a nem hagyományos, jelenleg is fejlesztés alatt álló témával kapcsolatban.

\section{Irodalom - References}

AGRCC — Australian Geothermal Reporting Code Committee 2010a: The Geothermal Reporting Code, Edition 2. — Australian Geothermal Energy Group and The Australian Geothermal Energy Association, 34 p.

AGRCC - Australian Geothermal Reporting Code Committee 2010b: Geothermal Lexicon for Resources and Reserves Definition and Reporting, Edition 2. - Australian Geothermal Energy Group and The Australian Geothermal Energy Association, 90 p. 
Вовок Е. 1987: Geotermikus energiatermelés. — Tankönyvkiadó, Budapest, 246 p.

Вовок Е. \& То́тн А. 2010: A hazai geotermikus energia agyon, kinyerô és hasznosító berendezések nyilvántartási rendszerének kidolgozása. - Kézirat, Geo-Energy Kft. MÁFGBA, Budapest, T.22097.

BoldizsÁR, T. 1967: Terrestrial heat and geothermal resources in Hungary. — Bulletin Vulcanologique 30, 221-227.

CGCC — The Canadian Geothermal Code Committee 2010: The Canadian Geothermal Code for Public Reporting. — Reporting of Exploration Results, Geothermal Resources and Geothermal Reserves, https://www.cangea.ca/uploads/3/0/9/7/30973335/ canadiangeothermalcodeforpublicreporting.pdf

Dolle, N. \& Falcone, G. 2009: Examples of Petroleum Resource Classification using the UNFC-2009. — Kézirat, 28 p.

Liebe P. (szerk.), Böcker T., Erdélyi M., Lorberer Á., Mike K., NAGy A., Székely F., Ágotai Gy. \& Balogh V. 1982: Az ország egyes régióin, területrészein a geotermikus potenciál meghatározása. — Kézirat, MFT munkabizottság. 1982. szeptember, MÁFGBA, Budapest. T.17968

LORBERER Á. 2004: A geotermális energiahasznosítás hazai fejlesztési koncepciója 2010-ig. — Kézirat, VITUKI.

NÁDOR A. 2016: A geotermikus energiavagyon nemzetközi osztályozási és jelentési rendszerei és a hazai adaptáció első lépései. — Földtani Közlöny 146/2, 123-134.

REZESSY G., SZANYI J. \& HÁMOR T. 2005: Jelentés a geotermikus energiavagyon állami nyilvántartásának előkészítéséről. I. fázis. — Kézirat, MÁFGBA, Budapest, T.21276, (CD).

Specifications for the application of the United Nations Framework Classification for fossil energy and mineral reserves and recources 2009 (UNFC-2009), Annex III. Bridging document between CRIRSCO Template and UNFC-2009. — https://www.unece.org/ fileadmin/DAM/energy/se/pdfs/UNFC/unfc2009_RE_Specs_publcomm_14/RE_Specs_12.06.2014.pdf, 17-22.

Zilahi-Sebess L., Merényi L., Paszera Gy., Tóth Gy., Boda E. \& Budai T. 2012: A hazai ásványi nyersanyag-potenciál. 5. Geotermikus energia (Háttértanulmány). — Kézirat, Nemzeti Energiastratégia, Készletgazdálkodási és hasznosítási cselekvési terv. MFGI, Budapest, 84 p.

ZILAHI-SEBESS, L. \& BodA, E. 2015: Recommended principles of the qualifications of geothermal plays. — Extended abstract, 7th HRHU and 18th HU Geomathematical Congress, 21-23 May, 2015, 5 p.

Kézirat beérkezett: 2016. 09. 13. 